\title{
THE USE OF PLANTS FOR FENCING AND FUELWOOD IN MUSTANG DISTRICT, TRANS-HIMALAYAS, NEPAL
}

\author{
Shandesh Bhattarai*, Ram P Chaudhary* and Robin SL Taylor** \\ *Central Department of Botany, Tribhuvan University, Kirtipur, Kathmandu, Nepal. \\ **Community Medicine, Queen’s University, Kingston, Ontario, Canada.
}

\begin{abstract}
The remoteness and difficult geography of Mustang in trans-Himalayas lead to continued use of wild plants for livelihood. Local people were interviewed during 2005-2007 and we recorded the use of 40 plant species belonging to 14 families under 22 genera as fence and fuelwood. The common parts of the plants used for fence and fuelwood are stems, branches and whole plant. Among 40 plant species, 36 species were used for fencing and 38 species as fuelwood. A total of 30 species with medicinal value were used as fence after cutting. Many plant species have duel uses as fence and fuelwood. In Mustang, suitable plant species are planted live or cut and used as dead fence around agricultural fields to protect the crops from damage by livestock and wild animals as well as prevent soil erosion by wind. Fuelwood is required to cook meals for themselves and feed for livestock, warm homes in the winter, and distil alcohol from the grain. Local communities have preference of using fuelwood on the basis of easy burning, durability and, accessibility and availability. There is need to encourage the practice of using live plant species as bio-fence in Mustang district, in particular in the upper Mustang. Alternative sources of energy have to be explored and practiced to reduce the dependency on fuelwood in upper Mustang for conservation of forest resources.
\end{abstract}

Key words: Plant species; Fencing; Fuelwood; Sustainability.

\section{INTRODUCTION}

A fence is a freestanding structure which is designed to restrict or prevent the movement of livestock, wild animals and peoples across a boundary. Mainly two types of fencing are used to protect agricultural fields in Nepal. Suitable live plant species such as shrubs, bushes or trees are tightly planted around the agricultural fields as hedgerows or cut and used as dead fence around the agricultural fields as a barrier. Fencing the agricultural fields with the plant species is an important old practice in the remote mountainous regions of Nepal to restrict the wild animal entry and to protect the loss of crops. Fuelwood, mainly obtained from tree trunk and branches of shrubs is used for cooking, and heating and is a principal component of rural domestic energy in Nepal. Both fence and fuelwood play an important role in livelihood of the people in trans-Himalayas, Nepal.

Mustang district is located in the mid-western development region of Nepal. The district is bounded on the south by Myagdi district, on the west by Dolpa district, on the east by Manang district, and on the north by the Tibetan Autonomous region of the Peoples Republic of China (see Figure 1 for the Location of Mustang District in the Annapurna Conservation Area of Nepal). The area is characterized by the high altitude, cold climate, semi-desert environment and rain shadow of Dhaulagiri and Annapurna Himal (KMTNC, 2004) with altitudinal variations of $1500 \mathrm{~m}$ to $8000 \mathrm{~m}$ (amsl). The total population of the district is 14,981 including speakers of Thakali, Nepali, Gurung languages living in an area of 3,639 $\mathrm{km}^{2}$ (CBS, 2004). The local economy is based on animal husbandry (pastoralism), subsistence agriculture and local trade.

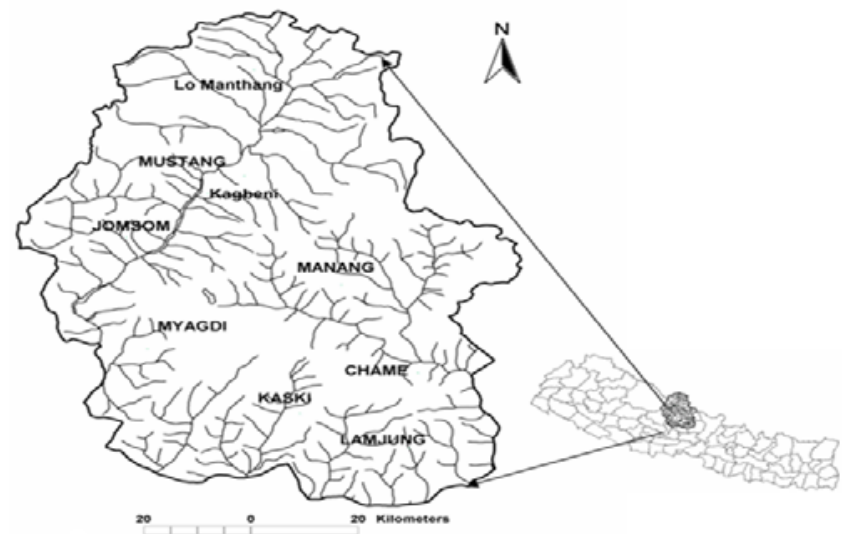

Figure 1: Location of Mustang District in the Annapurna Conservation Area (Source: NTNC, 2007).

The main aim of the study is to document the traditional knowledge on the utilization and assess importance of plant

Author for Correspondence: Shandesh Bhattarai, Central Department of Botany, Tribhuvan University, Kirtipur, Kathmandu, Nepal. 
species used for the fence and fuelwood by the local inhabitants of Mustang. This paper is focused on results obtained from field observations regarding the traditional applications of the plants used by the local people for fuelwood and fence. Mustang is one of the least explored districts in the field of ethnobotany, especially in comparison to other districts of Nepal. Most of the ethnobotanical works in Nepal have been conducted in the field of medicinal plants (Bhattarai et al., 2006b, 2007b) followed by general ethnobotany (Manandhar, 2002; Chhetri, 2005; Bhattarai, 2003; Bhattarai and Chaudhary, 2005, 2006; Bhattarai et al., 2006a, 2006b, 2007a, 2007b), and few studies (KMTNC 2002; 2004; Chhetri and Gupta, 2006, 2007; Bhattarai et al., 2009) have documented the traditional knowledge of plants in Mustang district. The harsh geography of Mustang has resulted to a local population with a strong reliance on indigenous knowledge for the fulfilment of their daily needs. A deeper understanding of the indigenous knowledge with respect to the plants belonging to fence and fuelwood categories, combined with grassroots initiatives could lead to improved sustainable development, means of survival and biodiversity conservation.

\section{MATERIALS AND METHODS}

Study Area. The present study was undertaken in and around the villages of Mustang district i.e., Ghasa, Lete, Sekung Taal, Larjung, Kalopani, Tukuche, Kobang, Kokhethanti, Marpha, Jomsom, Thini, Kagbeni, Eklebhatti, Jharkot, Mukthinath, Chhuksang, Chele, Samar, Syangboche, Ghemi, Dhakmar, Ghiling, Tamagaon, Jhaite, Bhena, Tsarang, and Lomanthang. Three field visits were made during the years 2005-2007 for the collection of ethnobotanical information.

The information was gathered by interviewing knowledgeable villagers. Interviews were conducted using the 'specimen display’ method. After collecting plant specimens for research, we showed those specimens to the locals in order to elicit any information. The same plant specimens were shown to different people to confirm the accuracy of the results (Taylor and Chaudhary, 2003). Consent for the research project was obtained in writing from the Annapurna Conservation Area Project, Pokhara, and verbally from each villager before they were interviewed. The project was approved by the Central Department of Botany, Research Committee of Tribhuvan University, Nepal.

Ranking of commonly used Fence and Fuelwood Plants. Information used to rank the local most preference of 3-4 species used as fence and fuelwood was obtained by interviewing the local communities. The ranking criteria for fuelwood include burning (easy burning with less smoke), durability (burning for a long time), extensive use and easy accessibility. Similarly, extensive use and easy accessibility are the ranking criteria for fencing. A total of 50 informants contributed to ranking.

Herbarium Specimens were collected and identified with the help of standard literatures (Polunin and Stainton, 1984; Stainton, 1988; Grierson and Long, 1983-2000), and nomenclature of the identified species follows (APG, 2003; Hara and Williams, 1979; Hara et al., 1982, 1978; Press et al., 2000). A set of Voucher Herbarium Specimens was made for each collection and the Voucher numbers are listed below in Table 1. These Vouchers have been deposited in the Tribhuvan University Central Herbarium (TUCH), Nepal.

\section{RESULTS}

The present study recorded 40 plant species belonging to 14 families under 22 genera which are being used as fence and fuelwood in Mustang. Among these plant species, 13 are trees and the remaining 27 are shrubs. Of fourteen families recorded, Rosaceae consists of highest number (9 species), followed by Berberidaceae (6 species), Fabaceae (5 species), Cupressaceae (4 species), and Pinaceae (3 species). Thirtysix species were used as a source of fence and 38 species were used as fuelwood. The common parts of the plants used for fence and fuelwood are stems, branches and whole plant. The results are presented in Table 1.

Out of the 36 plant species used for fence, Salix babylonica, Populus ciliata, Rosa sericea and Berberis species were most often cut for fences that are found around crop fields. Four plant species Hippophae salicifolia, Populus ciliata, Rosa sericea and Salix babylonica were used as living fences. In Mustang, the most preferred species under aforestation as 'living fences' are Salix babylonica and Populus ciliata. Aforestation is the artificial establishment of forests by planting or seeding in an area of non- forest land. In total, 30 species having medicinal value were cut for fencing, including Abies spectablis, Berberis species, and Juniperus species.

The most common tree species used for fuelwood in Mustang is Juniperus indica, which is preferred by the local communities because of good burning quality, burning durability, and easy availability. Pinus wallichiana is ranked second because it is used extensively and is easily available in Mustang. The third most common tree species ranked for fuelwood is Betula utilis, which is preferred because of good burning quality. In addition to the above tree species, some of the commonly used bushy shrubs for fuelwood are: Caragana species, Astragalus species, Juniperus species, Rosa species, and Berberis species.

\section{DISCUSSION}

Bio-fencing. Fencing is important to prevent wild as well as domestic animals from entering to crop fields. Plant species having spines, thorns, or frequent branching are mostly preferred for bio-fencing (Bhattarai et al., 2007a). In the remote areas, local people grow some of these species around the field permanently as a 'living fence' or 'bio-fence', while some are cut and placed as a temporary barrier (see Table 1) to help to stop soil erosion and act as a wind break.

Homogenous (fence with one plant species) as well as heterogeneous (fence two or more plant species) fencing are seen in Mustang but heterogeneous fences are most common. The local people tend to use heterogeneous fencing because of lack of abundance of one species used as fence. In addition to the common use of wild plants for fencing, the Annapurna 
Table 1: Fence and Fuelwood Plants of Mustang district, north-central, Nepal.

\begin{tabular}{|c|c|c|c|c|c|c|c|}
\hline \multirow{2}{*}{ Plant species } & \multirow{2}{*}{ Family } & \multicolumn{2}{|c|}{ Type of Fence* } & \multirow{2}{*}{ Fuel } & \multirow{2}{*}{ Voucher } & \multirow{2}{*}{ Local name } & \multirow{2}{*}{$\begin{array}{l}\text { Uses (medicinal and } \\
\text { food value) }\end{array}$} \\
\hline & & Living & Dead & & & & \\
\hline Abies spectabilis (D. Don) Mirb. & Pinaceae & $x$ & $\checkmark$ & 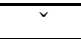 & 2096 & Gobre Salla (Nepali) & $x$ \\
\hline $\begin{array}{l}\text { Acanthopanax cissifolius (Griff. ex } \\
\text { Seem.) Harms }\end{array}$ & Araliaceae & $x$ & $x$ & $\checkmark$ & 2994 & Panghroo (Thakali) & Medicinal \\
\hline Alnus nepalensis D. Don & Betulaceae & $\times$ & $\checkmark$ & $\sim$ & 2977 & Utish (Nepali) & Medicinal \\
\hline $\begin{array}{l}\text { Astragalus candolleanus Royle ex } \\
\text { Benth. }\end{array}$ & Fabaceae & $x$ & $\checkmark$ & $\sim$ & 4031 & Manghpujhaa (Thakali) & $x$ \\
\hline Astragalus rhizanthus Benth. & Fabaceae & $x$ & $\checkmark$ & $\checkmark$ & 4032 & Manghpujhaa (Thakali) & $x$ \\
\hline Berberis aristata DC. & Berberidaceae & $\times$ & 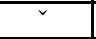 & 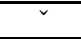 & 4567 & Karya (Gurung) & Medicinal, eaten raw \\
\hline Berberis koehneana C.K. Schneid. & Berberidaceae & $\times$ & $\sim$ & $\sim$ & 3549 & Kerwa (Amchi) & Medicinal, eaten raw \\
\hline $\begin{array}{l}\text { Berberis angulosa Wall. ex Hook. f. } \\
\text { \& Thomson }\end{array}$ & Berberidaceae & $\times$ & $\checkmark$ & $\sim$ & 3557 & Kyunudzu (Gurung) & Medicinal, eaten raw \\
\hline Berberis mucrifolia Ahrendt & Berberidaceae & $\times$ & $\checkmark$ & 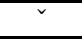 & 4010 & Kerwa (Amchi). & Medicinal, eaten raw \\
\hline Berberis ceratophylla G. Don & Berberidaceae & $x$ & $\checkmark$ & $\checkmark$ & 4334 & Kyerpa (Gurung) & Medicinal, eaten raw \\
\hline Berberis lycium Royle & Berberidaceae & $x$ & $\sim$ & $\sim$ & 4010 & Kirmuree Phal (Amchi) & Medicinal, eaten raw \\
\hline Betula utilis D. Don & Betulaceae & $x$ & $\sim$ & $\sim$ & 2031 & Buspath (Gurung) & $x$ \\
\hline Caragana brevispina Royle & Fabaceae & $x$ & $\checkmark$ & $\checkmark$ & 5432 & Thangchhar (Amchi) & Medicinal \\
\hline Caragana jubata (Pall.) Poir. & Fabaceae & $\times$ & $\checkmark$ & 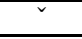 & 4041 & Thanglang (Thakali) & Medicinal \\
\hline Caragana gerardiana Royle & Fabaceae & $x$ & $\sim$ & $\sim$ & 4006 & Tanglikhtha (Amchi) & Medicinal \\
\hline $\begin{array}{l}\text { Cotoneaster bacillaris Wall. ex } \\
\text { Lindl. }\end{array}$ & Rosaceae & $x$ & $\sim$ & $\sim$ & 4036 & Jakshingh (Amchi) & Eaten raw \\
\hline $\begin{array}{l}\text { Cotoneaster microphyllus Wall. ex } \\
\text { Lindl. }\end{array}$ & Rosaceae & $x$ & $\checkmark$ & $\sim$ & 4037 & Jakshingh (Amchi) & Eaten raw \\
\hline \begin{tabular}{|l|} 
Cotoneaster affinis Lindl. \\
\end{tabular} & Rosaceae & $\times$ & 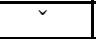 & $\bar{v}$ & 4445 & Phanghamaa (Amchi) & Medicinal, Eaten raw \\
\hline $\begin{array}{l}\text { Cotoneaster integrifolius (Roxb.) G. } \\
\text { Klotz }\end{array}$ & Rosaceae & $x$ & $\checkmark$ & $\checkmark$ & 4016 & Kukchhathha (Amchi) & Eaten raw \\
\hline \begin{tabular}{|l|l} 
Cupressus torulosa D. Don \\
\end{tabular} & Cupressaceae & $\times$ & $\checkmark$ & $\checkmark$ & 4017 & Ghueejhokphha (Gurung) & Medicinal \\
\hline Ephedra gerardiana Wall. ex Stapf & Ephedraceae & $\times$ & $x$ & $\checkmark$ & 4008 & Somalatha (Gurung) & Medicinal \\
\hline Hippophae salicifolia D. Don & Elaeagnaceae & $\sim$ & $\sim$ & $\sim$ & 2985 & Tarbu (Gurung) & Medicinal, eaten raw \\
\hline Hippophae tibetana Schleecht. & Elaeagnaceae & $\times$ & $\sim$ & $\times$ & 3082 & Tarbu (Gurung) & Medicinal, eaten raw \\
\hline Juglans regia L. & Juglandaceae & $\times$ & $\checkmark$ & $\checkmark$ & 2135 & Katutun (Gurung) & Medicinal, eaten raw \\
\hline Juniperus indica Bertol. & Cupressaceae & $x$ & $\sim$ & $\sim$ & 2956 & For (Gurung) & Medicinal \\
\hline $\begin{array}{l}\text { Juniperus squamata Buch.-Ham. ex } \\
\text { D. Don }\end{array}$ & Cupressaceae & $\times$ & $\checkmark$ & $\sim$ & 3543 & Sukri (Gurung) & Medicinal \\
\hline \begin{tabular}{|l|} 
Juniperus communis L. \\
\end{tabular} & Cupressaceae & $\times$ & $\checkmark$ & $\sim$ & 3086 & Phar (Gurung) & Medicinal \\
\hline $\begin{array}{l}\text { Lonicera myrtillus Hook. f. \& } \\
\text { Thomson }\end{array}$ & Caprifoliaceae & $x$ & $\sim$ & $\checkmark$ & 3562 & Phanghamaa (Amchi) & Medicinal, Eaten raw \\
\hline $\begin{array}{l}\text { Lonicera rupicola Hook. f. \& } \\
\text { Thomson }\end{array}$ & Caprifoliaceae & $x$ & $\checkmark$ & $\sim$ & 3550 & Phanghamaa (Amchi) & Medicinal, Eaten raw \\
\hline Pinus wallichiana A.B. Jacks. & Pinaceae & $\times$ & $\checkmark$ & $\checkmark$ & 3061 & Thansin (Gurung) & Medicinal \\
\hline Populus ciliata Wall. ex Royle & Salicaceae & $\sim$ & $\sim$ & $\checkmark$ & 3231 & Bhotapipal (Thakali) & Medicinal \\
\hline Prunus armeniaca L. & Rosaceae & $\times$ & $\times$ & $\bar{v}$ & 4028 & Khurpani (Gurung) & Medicinal, Eaten raw \\
\hline Prunus himalaica Kitam. & Rosaceae & $\times$ & $\times$ & $\checkmark$ & 3556 & Khambhu (Amchi) & Medicinal, Eaten raw \\
\hline Rosa macrophylla Lindl. & Rosaceae & $\times$ & 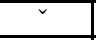 & 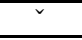 & 3109 & Seghu (Gurung) & Medicinal, eaten raw \\
\hline Rosa sericea Lindl. & Rosaceae & 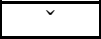 & $\sim$ & 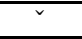 & 3110 & Sewa (Gurung) & Medicinal, eaten raw \\
\hline Rubus foliolosus D. Don & Rosaceae & $\times$ & $\checkmark$ & $\times$ & 2019 & Mapalan (Gurung) & Medicinal, eaten raw \\
\hline Rhododendron arboreum Sm. & Ericaceae & $\times$ & $\checkmark$ & 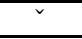 & 3064 & Gurans (Nepali) & Medicinal \\
\hline Salix babylonica L. & Salicaceae & 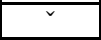 & $\bar{v}$ & $\approx$ & 4002 & Jankchhar (Thakali) & Medicinal \\
\hline Taxus wallichiana Zucc. & Taxaceae & $x$ & 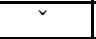 & 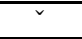 & 3056 & Silingi (Gurung) & Medicinal \\
\hline Tsuga dumosa (D. Don) Eichler & Pinaceae & $x$ & $\checkmark$ & $\checkmark$ & 3071 & Thinge Salla (Nepali) & $\times$ \\
\hline
\end{tabular}

Key: $\mathrm{i}$ indicates local use, while $\times$ indicates the opposite (not used as fencing or burned as fuel, as the case may be).

Conservation Area Project also encourages the construction of stone walls as fence. The stone walls eliminate the need to use often scarce wild fence plants. As fence protects the crop plants from damage by animals, both types of fences made of plant material and those of stone construction are highly valued in Mustang.

A total of 30 species with medicinal value were cut to construct fences. Documentation of bio-fencing plants in the control of human's diseases has been gaining importance (Reddy, 2008). Therefore further research on these bio-fencing/biomedicinal plants of Mustang may help in developing effective drugs of plant origin for human health care.
Fuelwood. In Mustang, fuelwood is required to cook meals for themselves and feed for livestock, warm homes, and distil alcohol from local grain. Approximately $34 \%$ of the above fuel energy requirement in upper Mustang is provided by burning the wild plant species (KMTNC, 2002). People collect large amounts of fuelwood during the months of April-July, which is then stored away for the snowy seasons (NovemberApril). All households of the one village have equal access to fuelwood for collection. Fuelwood consumption is $3.1 \mathrm{~kg}$ of wood per person per day (1.1 ton per person per annum), which is equal to 6,123.6 metric ton/annum for a total population of 5,412 in upper Mustang (KMTNC, 2002; CBS, 2001). Such a high consumption pattern may not be 
sustainable in the long term in the remote villages of the district which are located far from the natural forest.

Out of 38 plant species used for fuelwood, there are 19 species of trees and shrubs that meet majority of fuelwood demand in Mustang, and the remaining 19 species supplement the need. The most preferred plant species for fuelwood in Mustang is Juniperus indica.

In Trans-Himalayan regions of Nepal, people consume relatively more fuelwood than other regions because of the cold weather which also increases the requirements of fuel in the remote areas of upper Mustang. To meet the demand of fuelwood, people have been uprooting different types of thorny bushes because the villages are geographically isolated and are located far from the natural forest. Uprooting species of the family Fabaceae (including Caragana species and Astragalus species) is a risk to the ecosystem in the area because these plant species fix atmospheric nitrogen and are well adapted to the trans-Himalayan climate only among a few. Dense populations of Caragana species and Astragalus species are found in pastures and around crop fields in upper Mustang where they improve the habitat for associated plant species. Most often sheep and goats graze them also as fodder. The practice of uprooting these important species to meet the demand for fuelwood may cause a 'domino effect' which could lead to the extinction of valuable floral and faunal species.

Fuelwood collection, health issue and sustainability: Fuelwood is generally collected in a doko, a traditional bamboo basket carried on the back (one doko can contain approximately $30 \mathrm{~kg}$ of wood). The forests of lower Mustang are located close to villages, allowing fuelwood collection to take place up to three times a day. The situation differs in the upper Mustang (including Lomanthang, Ghemi, Dhakmar, Tsarang and Chhoser) which is geographically isolated and lies far from the natural forest. It is difficult for people to walk up a long distance needed to collect fuelwood. People in those areas have been using livestock dung, including goat and sheep pellets as an alternate source of fuelwood. In remote villages of upper Mustang, approximately $34 \%$ of fuel energy requirements is provided by the use of livestock dung (dung of cows, yaks, chauri, mule, horses, etc), followed by $32 \%$ by the use of sheep or goat pellets (KMTNC, 2002).

The use of alternatives to fuelwood may be seen as an environmentally sound option, but burning smoky biofuels on poorly ventilated stoves, 'chulo' in Nepali, can lead to health problems. A recent research study showed that the risk of asthma in Nepalese children was 2.2 times higher when they were exposed to the indoor use of smoky fuels than those not (odds ratio adjusted for cattle kept inside the house, tobacco smoke, and poultry) (Melsom et al., 2001). Other health issues from indoor use of smoky fuels include an increased risk of developing tuberculosis in India (Mishra et al., 1999), and a strong association with chronic obstructive pulmonary disease (COPD) was seen in Spain (Orozco-Levi et al., 2006).

Stability in heating and cooking fuel is of utmost importance. Access to kerosene and biogas used for gas stoves depends on transport and can be limited in times of civil unrest, bad weather, or insufficient funds (Bhattarai et al., 2007a). Presently majority of the people in Mustang have been using fuelwood, however, this practice may not be sustainable due to increasing population, migrant workers (collecting medicinal plants), and number of tourist/trekkers (Bhattarai et al., 2007a). The road construction has joined lower Mustang to Mukthinath that will increase the number of tourists to visit the area, leading to increase in the amount fuelwood consumption, and thus bringing a negative impact on forest resources.

Upper Mustang has a smallest forest area in Chhuksang (16 $\mathrm{km}^{2}$ ) but the forest is heavily exploited by the Khampas (Tibetan refugees) and there is now a scarcity of fuelwood (Boselli et al., 2005). Two popular fuelwood species, Salix babylonica and Populus ciliata are now afforested in large scale around crop fields in Mustang district. The aforestation practices of the two species were first supported by the Annapurna Conservation Area Project (ACAP) and this practice was continued with interest of the local people of Mustang. This aforestation practice has created awareness towards the conservation and management of wild plant resources. On trial basis aforestation practices of other potential species Hippophae salicifolia, Prunus species, Rosa sericea, Rosa macrophylla, Juglans regia having food and medicinal value could be cultivated as fence that would also provide nutrition to the local communities, treat common diseases (Bhattarai et al. 2006b) and help to conserve wild plant resources.

We have also observed the awareness among the people about the importance of forest resources for environmental conservation and their needs in a harsh climatic condition. Now-a-days the awareness programme is lead by the spiritual leaders of the community, governmental and nongovernmental organizations. We realized that such awareness programmes are crucial for the future long-term sustainable conservation and management of the resources of Mustang by using different alternative sources of energy to reduce current consumption of fuelwood as well as to cultivate plant species as bio-fences.

In conclusion, there is need to encourage the practice of using live plant species as biofence in Mustang district, in particular in the upper Mustang. Alternative sources of energy have to be explored and practiced to reduce the dependency on fuelwood in upper Mustang.

\section{ACKNOWLEDGEMENTS}

The authors (SB and RPC) are thankful to Volkswagen Foundation, Germany for providing financial support for field work. We are grateful to the people of the Mustang district of Nepal for their valuable ethnobotanical information and to 
the Annapurna Conservation Area Project (ACAP) for research permission for the field work.

\section{REFERENCES}

Bhattarai, S. 2003. Ethnobotanical study of Manang district and antibacterial activities of some selected medicinal plants. Central Department of Botany (M.Sc. Dissertation), Tribhuvan University, Kirtipur, Kathmandu, Nepal.

Bhattarai, S. and Chaudhary, R.P. 2005. Ethnobotany of wild rose in Manang district, Central Nepal. Environmental Biology and Conservation. 10: 33-36.

Bhattarai, S. and Chaudhary, R.P. 2006. Ethnobotany of Wild Allium species in Manang District, Central Nepal. Plant Archives. 6 (2): 471-476.

Bhattarai, S., Chaudhary, R.P. and Taylor, R.S.L. 2006a. Ethnomedicinal plants used by the people of Manang district, Central Nepal. Journal of Ethnobiology and Ethnomedicine. 2:41.

Bhattarai, S., Chaudhary, R.P. and Taylor, R.S.L. 2006b. Ethnobotany of wild Junipers (Juniperus species) in Manang district, central Nepal. Scientific world. 4(4): 109-112.

Bhattarai, S., Chaudhary, R.P. and Taylor, R.S.L. 2007a. Plants used as fence and fuelwood in Manang district, Central Nepal. Scientific World. 5(5): 107-111.

Bhattarai, S., Chaudhary, R.P. and Taylor, R.S.L. 2007b. Prioritization and trade of ethnomedicinal plants by the People of Manang district, Central Nepal. In R.P., Chaudhary, T.H., Aase, O.R., Vetaas, B.P., Subedi, (eds.), Local Effects of Global Changes in the Himalayas: Manang, Nepal. 151-169. Tribhuvan University, Nepal and University of Bergen, Norway.

Bhattarai, S., Chaudhary, R.P. and Taylor, R.S.L. 2009. Non-Medicinal uses of selected wild plants by the people of Mustang district, Nepal. J. Nat. Hist. Mus. 24: 48-58.

Boselii, A.M., Caravello, G.U. and Baroni, A. 2005. The Upper Mustang (Nepal) Ecosystem: Population, water quality and tourism. Aquatic ecosystem Health and Management. 8(3): 285-291.

CBS. 2001. Statistical year book of Nepal 2000. Central Bureau of Statistics, Thapathali, Kathmandu, Nepal.

CBS. 2004. Mustang District: An Introduction (Manang Jilla: Yek Parichaya, in Nepali).Central Bureau of Statistics, Thapathali, Kathmandu, Nepal (A leaflet).

Chhetri, R.B. 2005. Ethnobotany of bio-fencing in Dhulikhel region in Nepal. Ethnobotany. 17: 176-178.

Chhetri, H.B. and Gupta, V.N.P. 2006. NTFP Potential of Upper Mustang-A Trans-Himalayan Region in Western Nepal. Scientific World. 4(4): 38-43.

Chhetri, H.B. and Gupta, V.N.P. 2007. A survey of Non-timber Forest Products (NTFPs) in Upper Mustang. Scientific World. 5(5):89-94.

Grierson, A.J.C. and Long, D.G. 1983-2000. Flora of Bhutan. Vol. I \& II. Part. I-III. Royal Botanic Garden, Edinburgh and Royal Government of Bhutan.
Hara, H. and Williams, L.H.J. 1979. An Enumeration of the Flowering Plants of Nepal. Volume II. British Museum of Natural History, London.

Hara, H., Charter, A.O. and Williams, L.H.J. 1982. An Enumeration of the Flowering plants of Nepal. Volume III. British Museum of Natural History, London.

Hara, H., Stearn, W.T. and Williams, L.H.J. 1978. An Enumeration of the Flowering Plants of Nepal. Volume British Museum of Natural History, London.

KMTNC. 2002. Fuel energy in Upper Mustang: Demand, Supply and action plan for management. King Mahendra Trust for Nature Conservation, Annapurna Conservation Area Project, Research report series number 9. (NEP/99/GEF); NEP/99/021 (TRAC).

KMTNC. 2004. Annual Progress Report 2003-2004. King Mahendra Trust for Nature Conservation, Annapurna Conservation Area Project, Unit Conservation Office, Lomanthang.

Manandhar, N.P. 2002. Plants and People of Nepal. Timber Press, Inc., Portland, Oregon, U.S.A.

Melsom, T., Brinch, L., Hessen, J.O., Schei, M.A., Kolstrup, N., Jacobsen, B.K., Svanes, C. and Pandey, M.R. 2001. Asthma and indoor environment in Nepal. Thorax. 56(6): 477-81.

Mishra, V.K., Retherford, R.D. and Smith, K.R. 1999. Biomass cooking fuels and prevalence of tuberculosis in India. International Journal of Infectious Diseases. 3(3): 119-29.

NTNC. 2007. Annual Report 2007. National Trust for Nature Conservation, Jawalkhel, Lalitpur, Nepal.

Orozco-Levi, M., Garcia-Aymerich, J., Villar, J., Ramirez-Sarmiento, A., Anto, J.M. and Gea, J. 2006. Wood smoke exposure and risk of chronic obstructive pulmonary disease. European Respiratory Journal. 27(3): 542-6.

Polunin, O. and Stainton, A. 1984. Flowers of the Himalaya. Oxford Press, New Delhi, India.

Press, J. R., Shrestha, K.K. and Sutton, D.A. 2000. Annotated Checklist of the Flowering Plants of Nepal. Natural History Museum, London and Central Department of Botany, Tribhuvan University, Kathmandu.

Reddy, A.V.B. 2008. Use of various bio-fencing plants in the control of human diseases by the Lambada Tribe inhabiting Nalgonda District, Andhra Pradesh, India. Ethnobotanical Leaflets. 12: 520-523.

Stainton, A. 1988. Flowers of the Himalayas-A Supplement. Oxford University Press, New Delhi, India.

Taylor, R.S.L. and Chaudhary, R.P. 2003. Ethnobotanical Field Studies: Considerations for Researchers. Botanica Orientalis. Pp. 31-34.

The Angiosperm Phylogeny Group. 2003. An update of the Angiosperm Phylogeny Group classification for the orders and families of flowering plants: APG II. Botanical Journal of the Linnean Society. 141: $399-436$ 